\title{
An evaluation of the preoperative hemoglobin level as a prognostic factor for oral squamous cell carcinoma
}

\author{
Claudia Cordella, Heinz-Theo Luebbers ${ }^{*}$, Valentina Rivelli, Klaus W Grätz and Astrid L Kruse
}

\begin{abstract}
Background: Hypoxia seems to be an influencing factor for oral squamous cell carcinomas (SCC), and several immunohistochemical markers have been discussed in this regard. The aim of the present study was to evaluate preoperative hemoglobin levels as a prognostic factor for oral SCC.

Materials and methods: The files of 287 patients who had been treated for oral SCC between 1999 and 2008 were studied retrospectively. Hemoglobin levels between 1 and 5 days prior to surgical treatment were compared to Tumor (T)- and Nodal (N)- status, local recurrence, and lymph node metastases rate. The minimum follow-up period was 12 months.
\end{abstract}

Results: From a total of 287 patients with oral SCC, 205 (71.4\%) were in the normal hemoglobin $(\mathrm{Hb})$ group (female $\mathrm{Hb} \geq 12.0 \mathrm{~g} / \mathrm{dll}$; male $\mathrm{Hb} \geq 13.0 \mathrm{~g} / \mathrm{dl}$ ), 53 (18.5\%) in the mild anemia (female $\mathrm{Hb}=11.0-11.9 \mathrm{~g} / \mathrm{dl}$; male $\mathrm{Hb}=$ 11.0-12.9 g/dl), and $29(10.1 \%)$ in the severe anemia group (female \& male $\mathrm{Hb}<11.0 \mathrm{~g} / \mathrm{dl}$ ). Anemia was significant for the development of lymph node metastasis $(p=0.005)$ as well as for local recurrence $(p=0.001)$. No significant correlation was found to the initial T status ( $p=0.183)$.

Conclusion: Our data suggests that an $\mathrm{Hb}$ of below $11 \mathrm{~g} / \mathrm{dl}$ contributes to and is an indicator for a poor prognosis. Consequently, pre-treatment $\mathrm{Hb}$ corrections may significantly improve outcome, but further investigations, including blood transfusion/application of erythropoietin due to tumor anemia, independent of intraoperative blood-loss are necessary to ascertain their role in an improved survival.

\section{Background}

The estimated number of newly diagnosed cancers of the oral cavity and pharynx is 97,800 per year in Europe; the estimated number of deaths due to these carcinomas is 40,100 per year [1]. Despite improved diagnostic tools, chemotherapy, radiotherapy, and improved surgical techniques, the 5-year survival rate for head and neck cancer seems to be unchanged over the last two decades.

Clinical features and progression can differ greatly: some tumors develop no metastases, while others infiltrate at a very early stage and develop lymphangiomatosis or perineural invasion; such complications are not limited to well known risk factors such as smoking,

\footnotetext{
* Correspondence: t.luebbers@gmail.com

Department of Craniomaxillofacial and Oral Surgery, University Hospital Zurich, (Frauenklinikstr. 24), Zürich, (CH-8091), Switzerland
}

alcohol consumption, poor mouth hygiene, or human papilloma virus (HPV). But the reason why the outcomes of some tumors are so much worse than those of others has still not been discovered. One of the most important prognostic factors for lymph node metastasis in head and neck cancer is tumor infiltration depth[2], but the reason for different histological growth patterns and lymphogenic metastases is still unknown.

Hypoxia seems to be an influencing factor for oral squamous cell carcinomas (SCC), and it is well known that the radiation doses needed to kill hypoxic cells are approximately 2-3 times higher than those needed to destroy well-oxygenated cells[3,4]. Most studies for head and neck SCC, however, deal with the effect of anemia as it relates to the outcome of radiotherapy[5,6]. Therefore, the question arises whether anemia also influences the outcome of surgical treatment. We have come across no studies which have dealt with this subject. 


\section{Materials and methods}

A total of 287 patients who were treated for oral SCC over a 10-year period between 1999 and 2008 at a single center (Clinic for Craniomaxillofacial and Oral Surgery, University Hospital Zurich) were evaluated retrospectively. All hemoglobin levels between 1 and 5 days prior to surgical treatment, Tumor (T)- and Nodal (N)-statuses, local recurrence rates, and lymph node metastases were taken into consideration. The minimum follow-up time was 12 months. Due to inadequate information and/or a followup time of less than 12 months, 82 patients were excluded. Using the normal hemoglobin $(\mathrm{Hb})$ values defined by the World Health Organization (WHO), the patients were divided into a three groups: normal (female $\mathrm{Hb} \geq 12.0 \mathrm{~g} / \mathrm{dl}$; male $\mathrm{Hb} \geq 13.0 \mathrm{~g} / \mathrm{dl}$ ), mild anemia (female $\mathrm{Hb}=11.0-11.9 \mathrm{~g} / \mathrm{dl}$; male $\mathrm{Hb}=11.0-12.9 \mathrm{~g} / \mathrm{dl})$, and severe anemia (female \& male $\mathrm{Hb}<11.0 \mathrm{~g} / \mathrm{dl}$ ), according to Becker et al. [5]

All data were primarily obtained for medical purpose under informed consent of the patients. The study design fulfills the criteria of paragraphs $4 \mathrm{a}$ and $\mathrm{b}$ according to the guidelines (version 21.5.2010.2010) of the cantonal ethics committee of Zurich and therefore is exempted from institutional review board approval. The study design thereby fulfills the guidelines of the Declaration of Helsinki about Ethical Principles for Medical Research Involving Human Subjects.

For statistical analysis, SPPS 18 for Mac was used. P value $<0.05$ was considered to be statistically significant. Kaplan-Meier analysis with log-rank testing was used for analysis.

\section{Results}

Out of 287 patients with oral SCC, 205 (71.4\%) were in the normal group, $53(18.5 \%)$ in the mildly anemic, and $29(10.1 \%)$ in the severely anemic group. The femalemale ratio was 121:166, and the median age 62.53 years. In the log rank test, anemia was significant for the development of lymph node metastasis $(p=0.005)$ as well as for the development of local recurrence ( $\mathrm{p}=$ 0.001) (Figure 1 and 2).

No association between $\mathrm{T}$ status and the development of local recurrence was found $(\mathrm{p}=0.183)$ (Figure 3$)$.

In the severe anemia group, 17 out of 29 patients (58.6\%) had T4 status; in the normal group, 58 out of 205 patients $(28.3 \%)$ had T4 status. There was a low number of patients with T3 status (Figure 4).

Lymph node metastases were observed in 45 out of $205(28.1 \%)$ patients in the normal group and, in the severe anemia group, 19 out of 29 (65.5\%) patients had positive lymph nodes (Figure 5).

\section{Discussion}

It is widely accepted that anemia causes radiation resistance because the $\mathrm{Hb}$ level presumably mediates tumor response to radiation through the delivery of oxygen to the tumor[5]. There is increasing evidence that low $\mathrm{Hb}$ levels are indeed associated with poor tumor oxygenation, and increasing $\mathrm{Hb}$ concentrations are correlated with higher pO2 levels and lower hypoxic tissue fractions[7]. Therefore, several authors advocate blood transfusions before radiotherapy for anemic patients [8-10].

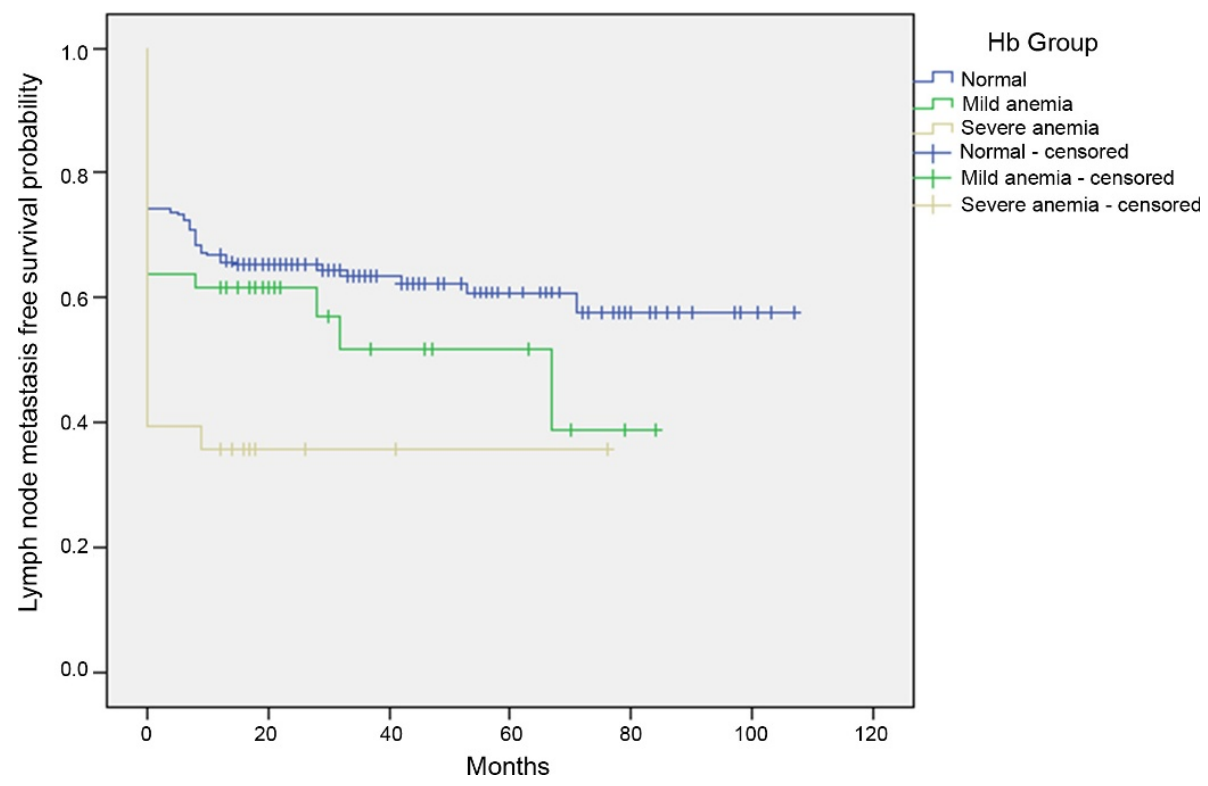

Figure 1 Kaplan-Meier curves of lymph node metastasis -free survival for patients without anemia, mild anemia, or severe anemia. 


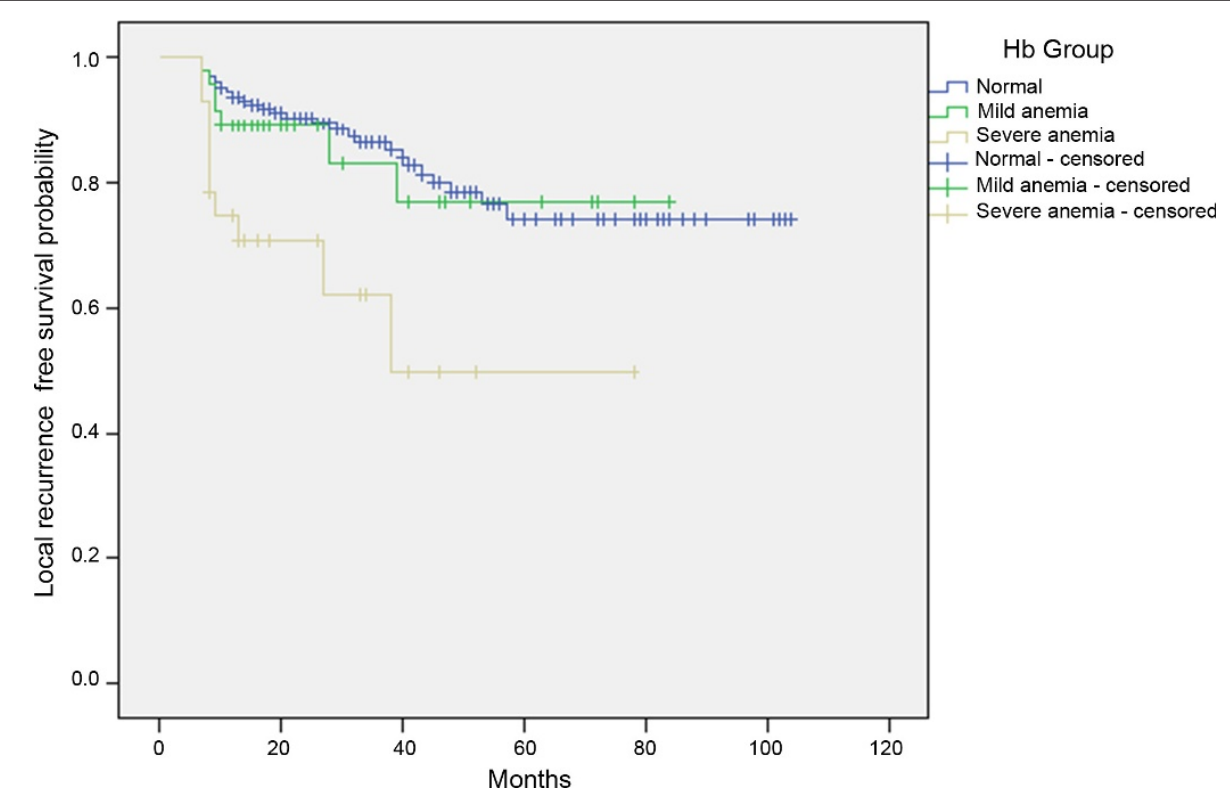

Figure 2 Kaplan-Meier curves of local recurrence-free survival for patients without anemia, mild anemia, or severe anemia

In the current study, low $\mathrm{Hb}$ levels were found to be associated with the development of lymph node metastasis $(\mathrm{p}=0.005)$. Concerning the development of local recurrence, anemia is also a prognostic factor $(\mathrm{p}$ $=0.001)$, but, surprisingly, not the initial $\mathrm{T}$ status $(\mathrm{p}=$ 0.183). These data suggest that a low Hb concentration contributes to poor prognosis; these findings were supported by the results of several previous studies[11,12].
One reason could be that hypoxia is induced via Hypoxia-inducible Factor- $1 \alpha$ (HIF-1 $\alpha$ ) and Vascular endothelial growth factor (VEGF), leading to a loss of p53[13].

If a low $\mathrm{Hb}$ concentration is a predictor of decreased local control, consequently, $\mathrm{Hb}$ corrections may significantly improve tumor oxygenation.

On the other hand, out of 29 patients in the severe anemia group, 17 had T4 tumors; therefore, large/

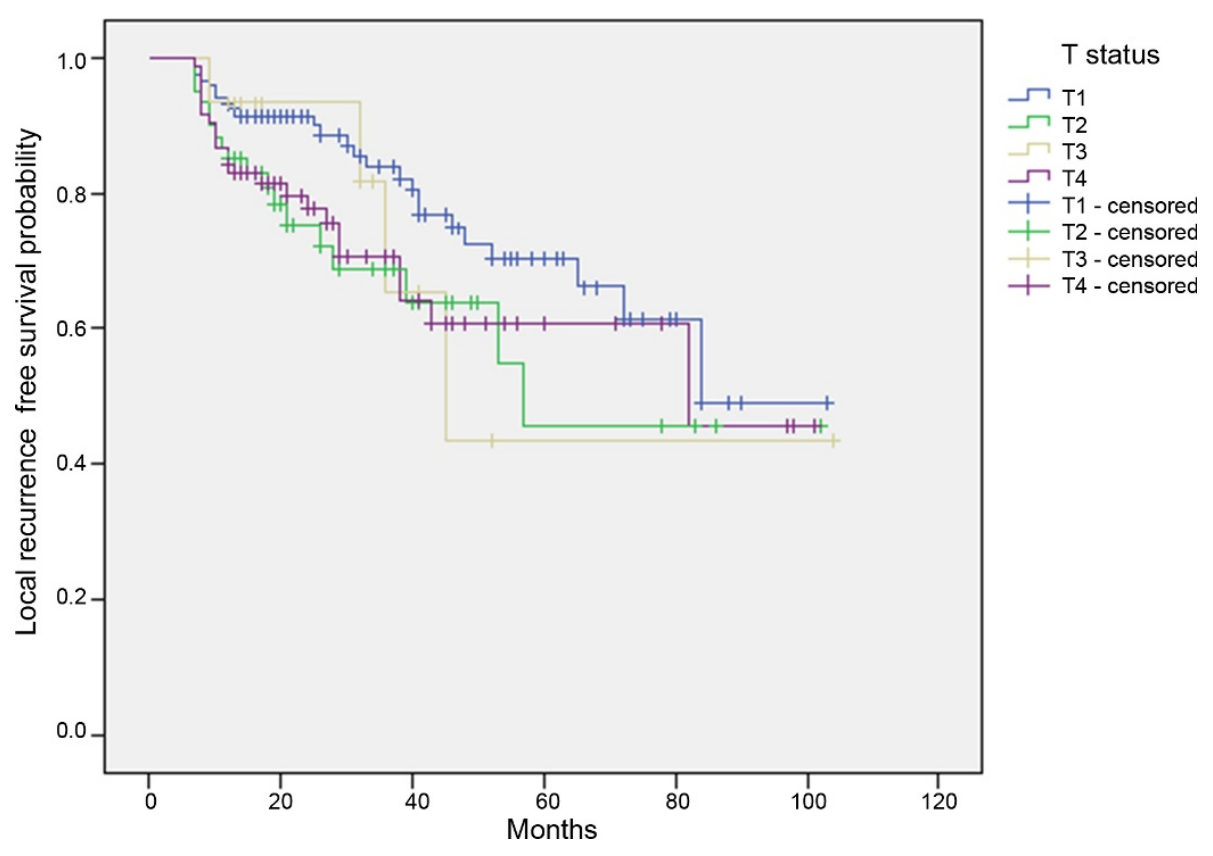

Figure 3 Kaplan-Meier curves of local recurrence-free survival for patients with T1-, T2-, T3-, and T4-status. 

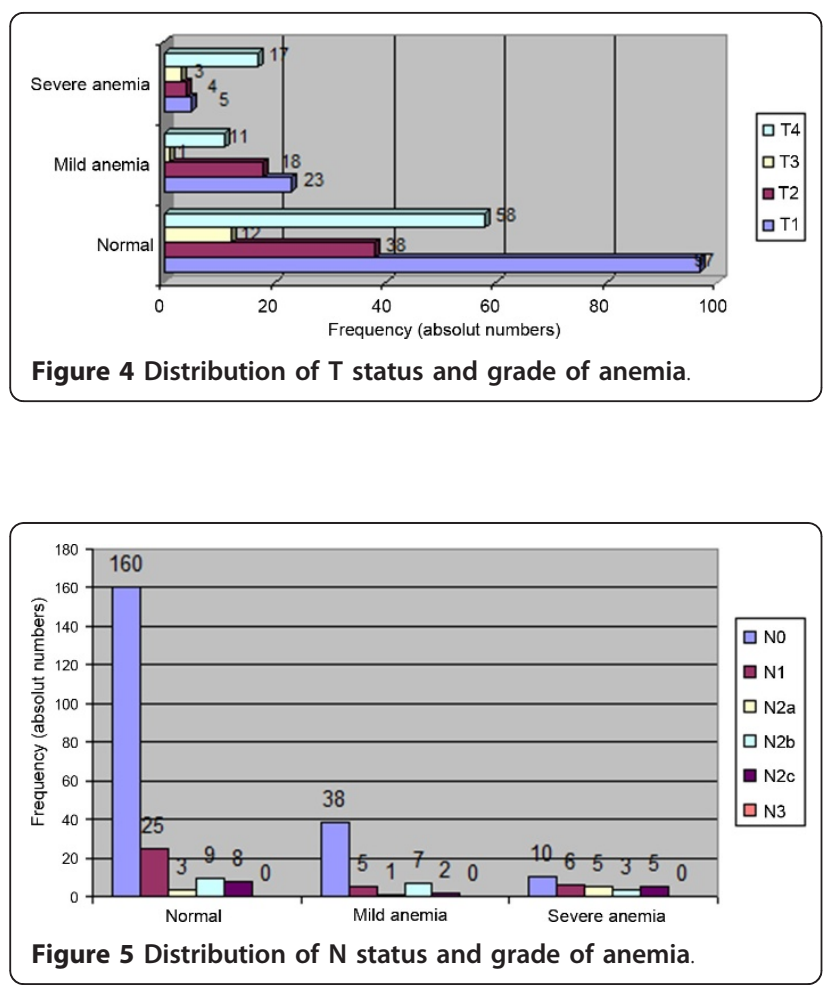

infiltrative tumors might have led to anemia. However our data did not reveal $\mathrm{T}$-status influence on local recurrence or lymph node metastases. Another reason could be the advanced stage of the disease. In the present study, $65.5 \%$ of patients with severe anemia had lymph node metastases, but, in the normal group, only $28.1 \%$ had positive lymph nodes.

However, if a lower $\mathrm{Hb}$ is associated with a worse outcome, one could conclude that blood transfusion could improve prognosis. To our knowledge, no study has dealt with this question. However, several studies have dealt with the need for intraoperative blood transfusion. (Table 1) This topic is not identical but somehow similar since low preoperative Hb-levels might - assumed surgical procedures are identical - lead to an intraoperative need for transfusion. However, evidence of a significant association between transfusion and prognosis in patients who undergo resection of oral SCC is conflicting: some authors have reported an influence $[14,15]$, while others did not confirm blood transfusion as a prognostic factor[16,17]. After all, one must also differentiate between blood transfusions for preoperative anemia and those for surgical procedure/bleeding, as mentioned above.

Table 1 Studies regarding blood transfusion in head and neck cancer patients

\begin{tabular}{|c|c|c|c|c|}
\hline Author & Patients (n) & Location & Outcome & Results \\
\hline Böck[24] & $\begin{array}{l}174 \\
\text { (141 with transfusion) }\end{array}$ & Larynx/hypopharynx & Recurrence, survival, infection & No influence \\
\hline Jones[25] & $\begin{array}{l}90 \\
\text { (46 with transfusion) }\end{array}$ & Head and neck & Recurrence & No influence \\
\hline Ell[26] & $\begin{array}{l}240 \\
\text { (113 with transfusion) }\end{array}$ & Larynx & Survival & No influence \\
\hline Woolley[27] & $\begin{array}{l}143 \\
\text { (99 with tranfusion) }\end{array}$ & Head and neck & Recurrence & $P<0.009$ \\
\hline Von Doersten[28] & $\begin{array}{l}104 \\
\text { (51 with transfusion) }\end{array}$ & Head and neck & Recurrence, infection & No influence \\
\hline Schuller[17] & $\begin{array}{l}217 \\
\text { (132 with transfusion) }\end{array}$ & Head and neck & Survival & No influence \\
\hline Barra[29] & $\begin{array}{l}207 \\
\text { (152 with transfusion) }\end{array}$ & Head and neck & Survival & $P<0.05$ \\
\hline Alun-Jones[30] & $\begin{array}{l}69 \\
\text { (38 with transfusion) }\end{array}$ & Larynx & Survival & $P<0.05$ \\
\hline Sturgis[14] & $\begin{array}{l}61 \\
\text { (25 with transfusion) }\end{array}$ & Head and neck & Recurrence & $\begin{array}{l}\text { Influence } \\
\text { (48\% with transfusion; } 24 \% \text { without transfusion) }\end{array}$ \\
\hline Leon[31] & $\begin{array}{l}269 \\
\text { (86 with transfusion) }\end{array}$ & Larynx & Recurrence & No influence \\
\hline Moir[32] & 165 (60 with transfusion) & Head and neck & Recurrence & $P<0.04$ \\
\hline Taniguchi[15] & $\begin{array}{l}105 \\
\text { (64 with transfusion) }\end{array}$ & Oral cavity & Survival & $P<0.01$ \\
\hline Szakmany[33] & $\begin{array}{l}559 \\
\text { (437 with transfusion) }\end{array}$ & $\begin{array}{l}\text { Oral cavity/ } \\
\text { Oropharyngeal }\end{array}$ & $\begin{array}{l}\text { Recurrence, } \\
\text { survival }\end{array}$ & $\geq 3$ units influence \\
\hline Fenner[16] & 223 & Oral cavity & Survival & No influence \\
\hline
\end{tabular}

Studies involving the effects of blood transfusion in head and neck cancer show inconsistent results 
For patients with colorectal, lung, or breast carcinoma, an immunosuppressive effect of blood transfusions leading to increased local recurrence has been discussed, but is doubted by some authors[18,19], and it has not been proven so far for head and neck cancer. There is also some laboratory evidence for an association between blood transfusion and tumor growth[20].

One hypothesized mechanism for a worsened prognosis in tumor patients undergoing blood transfusion is the presence of biologically active growth factors in stored blood products. These factors seem to leach from red blood cells [21-23]

The strength of this study lays in the high number of patients with a minimum follow-up time (12 months) compared to smaller numbers of patients with head and neck cancer written about in the literature.

The limitation of the study is its retrospective nature. Conversely, the analysis was restricted to those variables that could be retrieved reliably for every patient from our database. Therefore, the number of blood transfusions and the amount of intraoperative blood-loss were excluded. In addition, other risk factors such as smoking, alcohol use, and poor mouth hygiene were not included because that information was not known. The number of patients with T3 status in this study is low and not consistent with T-status distribution of SCC found in many other studies and is not the distribution one would expect. However, this fact should not influence the results.

The idea of advocating preoperative transfusion or erythropoietin administration prior to surgery has very important economic as well as physiologic consequences and, given the grade of evidence, we consider this idea only with caution. Further investigations are needed, including examination of blood transfusion/application of erythropoietin due to tumor anemia in a prospective setting with multivariate analysis to rule out dependency with other more important factors. The influence of all negative side effects possibly coming with the transfusion of blood products also needs to be addressed[21].

Also there are several reasons why patients with head and neck tumors may have low preoperative hemoglobin, such as nutritional deficiency, difficulties involving oral intake, and/or social deprivation. Anemia could also be a marker for other risk factors, such as p53 mutation, loss of heterozygosity ( $\mathrm{LOH}), \mathrm{HPV}$, etc. These factors should also be considered in future prospective studies.

In sum, the results of this study were not expected and no satisfying explanation is obvious. However, if it is found that $\mathrm{Hb}$ is not independent, it might still be an important and easily obtained marker for underlying conditions the cause for poor prognosis.

\section{Conclusion}

Our data suggest that a low $\mathrm{Hb}$ level contributes to poor prognosis in oral SCC patients. Consequently, Hb corrections may significantly improve outcomes, but further investigations are necessary to clear the role of $\mathrm{Hb}$ in outcome prediction for oral SCC.

\section{Authors' contributions}

VR and CC carried out the retrospective study, AK and CC drafted the manuscript, HTL drafted and finalized the manuscript, KG and AK participated in the design and coordination of the study. All authors read and approved the final manuscript.

\section{Competing interests}

The authors declare that they have no competing interests.

Received: 12 July 2011 Accepted: 15 August 2011

Published: 15 August 2011

\section{References}

1. Boyle P, Ferlay J: Cancer incidence and mortality in Europe, 2004. Ann Oncol 2005, 16:481-488.

2. Woolgar JA, Hall GL: Determinants of outcome following surgery for oral squamous cell carcinoma. Future Oncol 2009, 5:51-61.

3. Gray LH, Conger AD, Ebert M, Hornsey S, Scott OC: The concentration of oxygen dissolved in tissues at the time of irradiation as a factor in radiotherapy. Br J Radiol 1953, 26:638-648.

4. Evans NTS, Naylor PFD: The effect of oxygen breathing and radiotherapy upon the tissue oxygen tension of some human tumours. $\mathrm{Br} J$ Radiol 1963, 36:418-425.

5. Becker A, Stadler P, Lavey RS, Hansgen G, Kuhnt T, Lautenschlager C, Feldmann HJ, Molls M, Dunst J: Severe anemia is associated with poor tumor oxygenation in head and neck squamous cell carcinomas. Int J Radiat Oncol Biol Phys 2000, 46:459-466.

6. Brizel DM, Dodge RK, Clough RW, Dewhirst MW: Oxygenation of head and neck cancer: changes during radiotherapy and impact on treatment outcome. Radiother Oncol 1999, 53:113-117.

7. Vaupel P, Mayer A, Hockel M: Impact of hemoglobin levels on tumor oxygenation: the higher, the better? Strahlenther Onkol 2006, 182:63-71.

8. Warde P, O'Sullivan B, Bristow RG, Panzarella T, Keane TJ, Gullane PJ, Witterick IP, Payne D, Liu FF, McLean M, et al: T1/T2 glottic cancer managed by external beam radiotherapy: the influence of pretreatment hemoglobin on local control. Int J Radiat Oncol Biol Phys 1998, 41:347-353.

9. Kumar P: Tumor hypoxia and anemia: impact on the efficacy of radiation therapy. Semin Hematol 2000, 37:4-8.

10. Kumar P: Impact of anemia in patients with head and neck cancer. Oncologist 2000, 5(Suppl 2):13-18.

11. Hefler L, Mayerhofer K, Leibman B, Obermair A, Reinthaller A, Kainz C, Tempfer C: Tumor anemia and thrombocytosis in patients with vulvar cancer. Tumour Biol 2000, 21:309-314.

12. Qiu MZ, Yuan ZY, Luo HY, Ruan DY, Wang ZQ, Wang FH, Li YH, Xu RH: Impact of pretreatment hematologic profile on survival of colorectal cancer patients. Tumour Biol 2010.

13. Blancher C, Harris AL: The molecular basis of the hypoxia response pathway: tumour hypoxia as a therapy target. Cancer Metastasis Rev 1998, 17:187-194.

14. Sturgis EM, Congdon DJ, Mather FJ, Miller RH: Perioperative transfusion, postoperative infection, and recurrence of head and neck cancer. South Med J 1997, 90:1217-1224.

15. Taniguchi Y, Okura M: Prognostic significance of perioperative blood transfusion in oral cavity squamous cell carcinoma. Head Neck 2003, 25:931-936.

16. Fenner M, Vairaktaris E, Nkenke E, Weisbach V, Neukam FW, RadespielTroger M: Prognostic impact of blood transfusion in patients undergoing primary surgery and free-flap reconstruction for oral squamous cell carcinoma. Cancer 2009, 115:1481-1488. 
17. Schuller DE, Scott C, Wilson KM, Freer R, al-Sarraf M, Jacobs J, Ahmad K, Casiano R, Laramore G: The effect of perioperative blood transfusion on survival in head and neck cancer. Arch Otolaryngol Head Neck Surg 1994, 120:711-716

18. Akyol AM, Galloway DJ, George WD: Perioperative blood transfusion does not promote recurrence and death after mastectomy for breast cancer. Br J Surg 1992, 79:470

19. Donohue JH, Williams S, Cha S, Windschitl HE, Witzig TE, Nelson H, Fitzgibbons RJ Jr, Wieand HS, Moertel CG: Perioperative blood transfusions do not affect disease recurrence of patients undergoing curative resection of colorectal carcinoma: a Mayo/North Central Cancer Treatment Group study. J Clin Oncol 1995, 13:1671-1678.

20. Francis DM, Shenton BK: Blood transfusion and tumour growth: evidence from laboratory animals. Lancet 1981, 2:871.

21. Upile T, Jerjes W, Mahil J, Sudhoff H, Hopper C, Wright A: Blood product transfusion and cancer prognosis. Clin Adv Hematol Oncol 2009, 7:656-661.

22. Upile T, Jerjes W, Mahil J, Upile N, Sudhoff $H$, Wright A, Hopper C: An explanation for the worsened prognosis in some cancer patients of perioperative transfusion: the time-dependent release of biologically active growth factors from stored blood products. European archives of oto-rhino-laryngology: official journal of the European Federation of OtoRhino-Laryngological Societies 2011.

23. Upile T, Jerjes W, Sandison A, Singh S, Rhys-Evans P, Sudhoff H, Hopper C: The direct effects of stored blood products may worsen prognosis of cancer patients; shall we transfuse or not? An explanation of the adverse oncological consequences of blood product transfusion with a testable hypothesis driven experimental research protocol. Medical hypotheses 2008, 71:489-492.

24. Bock M, Grevers G, Koblitz M, Heim MU, Mempel W: Influence of blood transfusion on recurrence, survival and postoperative infections of laryngeal cancer. Acta Otolaryngol 1990, 110:155-160.

25. Jones KR, Weissler MC: Blood transfusion and other risk factors for recurrence of cancer of the head and neck. Arch Otolaryngol Head Neck Surg 1990, 116:304-309.

26. Ell SR, Stell PM: Blood transfusion and survival after laryngectomy for laryngeal carcinoma. J Laryngol Otol 1991, 105:293-294.

27. Woolley AL, Hogikyan ND, Gates GA, Haughey BH, Schechtman KB, Goldenberg JL: Effect of blood transfusion on recurrence of head and neck carcinoma. Retrospective review and meta-analysis. Ann Otol Rhinol Laryngol 1992, 101:724-730.

28. von Doersten P, Cruz RM, Selby JV, Hilsinger RL Jr: Transfusion, recurrence, and infection in head and neck cancer surgery. Otolaryngol Head Neck Surg 1992, 106:60-67.

29. Barra S, Barzan L, Maione A, Cadelano A, Pin M, Franceschi S, Comoretto R: Blood transfusion and other prognostic variables in the survival of patients with cancer of the head and neck. Laryngoscope 1994, 104:95-98.

30. Alun-Jones T, Clarke PJ, Morrissey S, Hill J: Blood transfusion and laryngeal cancer. Clin Otolaryngol Allied Sci 1991, 16:240-244.

31. Leon X, Quer M, Luz Maestre M, Burgues J, Muniz E, Madoz P: Blood transfusions in laryngeal cancer: effect on prognosis. Head Neck 1996, 18:218-224.

32. Moir MS, Samy RN, Hanasono MM, Terris DJ: Autologous and heterologous blood transfusion in head and neck cancer surgery. Arch Otolaryngol Head Neck Surg 1999, 125:864-868.

33. Szakmany T, Dodd M, Dempsey GA, Lowe D, Brown JS, Vaughan ED, Rogers SN: The influence of allogenic blood transfusion in patients having free-flap primary surgery for oral and oropharyngeal squamous cell carcinoma. Br J Cancer 2006, 94:647-653.

doi:10.1186/1758-3284-3-35

Cite this article as: Cordella et al: An evaluation of the preoperative hemoglobin level as a prognostic factor for oral squamous cell carcinoma. Head \& Neck Oncology 2011 3:35.

\section{Submit your next manuscript to BioMed Central and take full advantage of:}

- Convenient online submission

- Thorough peer review

- No space constraints or color figure charges

- Immediate publication on acceptance

- Inclusion in PubMed, CAS, Scopus and Google Scholar

- Research which is freely available for redistribution

Submit your manuscript at www.biomedcentral.com/submit
C Biomed Central 